3. Ракитянский Н. М. Портретология власти. М.: Наука, 2004. -263 с.

4. Хабибулин Р.К. Дистантное психологическое портретирование субъектов политической власти//Вестник СПбГУ, 2011. Серия 12. Выпуск 3 C.57-65

5. Шмелев А. Г. Психодиагностика личностных черт - СПб.: изд-во «Речь», 2002- 480c.

\title{
ПРОФЕССИОНАЛЬНО ВАЖНЫЕ КАЧЕСТВА В АДВОКАТСКОЙ ДЕЯТЕЛЬНОСТИ
}

Теплякова А.П.

Научный руководитель: к.псх.н., доцент Макаревская Ю.Э.

Адвокату, как и любому другому профессионалу, требуется иметь набор определённых профессионально важных качеств, для того, чтобы успешно осуществлять свою адвокатскую деятельность[7].

Мы, на основе профессиограмм различных юридических специальностей (судья; адвокат; прокурор; следователь), используя метод сравнительного анализа, исследовали профессионально важные качества адвоката с целью выявления его универсальных и специфических профессионально важных качеств, применяемых им при осуществлении адвокатской деятельности.

Исследуя профессиограмму судьи, мы пришли к выводу, что к основным профессионально важным качествам при осуществлении правосудия относятся: честность, принципиальность, искренность по отношению к себе и другим; добросовестность, которая неразрывно связана с чувством долга; беспристрастность, которая позволяет принимать справедливые судебные решения и равно относится к лицам, участвующим в деле. Так же судья должен обладать объективностью и наблюдательностью, а так же способностью к передаче и приему вербальной информации. Так же стоит отметить, что для судей свойственна эмоциональная сдержанность[1].

Проанализировав профессиограмму следователя, мы выявили, что к профессионально важным качествам деятельности следователя при осуществлении предварительного следствия относят: логическое и аналитическое мышление; хорошую память; развитый образ мышления; коммуникативные и организаторские способности; хорошее владение письменной речью; внимательность; аккуратность; терпеливость; усидчивость; ответственность; настойчивость; целеустремленность; эмоциональная устойчивость.

Исследовав профессиограмму прокурора, мы пришли к выводу, что к ПВК успешного прокурора относят: способности к абстрагированию, обладанием широкого кругозора. Прокурор должен обладать гражданским мужеством и чувствам долга, а так же способностью устанавливать и поддерживать психологический контакт с различными участниками общения, преодолевать психологические и коммуникативные барьеры другой стороны. 
Прокурор хорошо владеет средствами межличностного познания рефлексией и идентификацией[8]. К основными эмоционально-волевыми качествами, можно отнести толерантность к воздействию стресс-факторов, а так же высокий уровень волевого самоконтроля над эмоциями и поведением.

К ПВК адвоката относятся: качества, характеризующие социальную зрелость. Они обеспечивают высокий уровень правосознания, социальной ответственности, стремление к саморазвитию, позитивный взгляд на мир в целом [3]. Помимо глубоких профессиональных знаний адвокату необходимо иметь развитый интеллект, высокую умственную работоспособность, высокий уровень ораторских способностей, а что касаемо организаторских качеств - это инициативность, решительность, настойчивость и прочее. Они нужны адвокату в первую очередь для правильной организации своего рабочего времени, планирования рабочего графика [2]. К эмоционально-волевым качествам следует отнести; сдержанность, гибкость и развитые адаптивные свойства нервной системы.

Итак, проанализировав ПВК таких специальностей, как судья, следователь, прокурор, мы выявили, что универсальными качествами для всех вышеназванных специальностей, в том числе и адвоката, являются: честность, добросовестность, логичность, критичность и аналитический склад ума, а так же общительность, умение слушать, прогнозировать, дисциплинированность, самоконтроль над эмоциями и поведением, толерантность[4].

В ходе проведенного исследования, мы пришли к выводу, что специфическими ПВК адвоката, при осуществлении адвокатской деятельности является его ответственность за будущее своих клиентов, так как из всех вышеперечисленных специальностей только адвокат работает напрямую со своими клиентами, за счёт чего он и осуществляет свою профессиональную деятельность [5].

Так же большую роль в профессии адвоката играет его имидж, так как именно умение правильно подать себя, определяет насколько сильно, будет востребован адвокат в своей деятельности [6].

На наш взгляд, было бы интересно рассмотреть дальнейшую перспективу исследования таких профессионально важных качеств, которые разграничивают успешных адвокатов от менее успешных в своей сфере.

\section{Литература}

1. Аминов И.И.: Юридическая психология. - М.: ЮНИТИ-ДАНА, -2007. C. 126 .

2. Афанасьева О.В.: Этика и психология профессиональной деятельности юриста. - М.: Академия, - 2004. - С. 345.

3. Бойков, А.Д. Сущность и правовое содержание статуса адвоката А.Д, Бойков // Адвокат. - 2010. С. 111.

4. Васильев В.Л.: Юридическая психология. - СПб.: Питер, - 2009. -С.283.

5. Власов А.А. Значение судебной речи в адвокатской деятельности // Адвокатская практика. - 2012. - С. 45.

6. Ивакина Н.Н. Профессиональная речь юриста: Учебное пособие для вузов. - М.: Изд-во Норма, - 2010. - С. 103. 
7. Скабелина Л. А.: Психологические аспекты адвокатской деятельностиМосква. - 2012. - С. 68.

8. Чуфаровский Ю.В.: Юридическая психология. - М.: Проспект, - 2010. C. 115 .

\section{ОСОЗНАНИЕ СОДЕЯННОГО НЕСОВЕРШЕННОЛЕТНИМИ ОБВИНЯЕМЫМИ, КАК ОДИН ИЗ ВИДОВ ПРОЯВЛЕНИЯ ДЕФЕКТОВ ПРАВОВОЙ СОЦИАЛИЗАЦИИ \\ Церекидзе Я.В., Шуванов И.Б.}

Социализация личности - одна из тех проблем познания, актуальность изучения которой не ослабевает с течением времени. Если же говорить о современном российском обществе, которое находится на данный момент на этапе трансформации, необходимость разработки проблемы социализации только усиливается.

Исходя из вышеизложенного, следует сказать, что вопросом социализации личности посвящено большое количество работ отечественных и зарубежных философов, социологов и психологов, таких как: Ст.Холл, А.Гезел, З.Фрейд, В.Скиннер, А.Бандура, Л.Колберг, Э.Эриксон, А.Оллпорт, А.В.Петровский, Ж.Пиаже и др.

В следствии такой научной заинтересованности социализацией личности, сформировалось множество подходов и теорий. Обобщая данные подходы к определению понятия « социализация», можно отметить, что данный процесс рассматривается как активное усвоение индивидом социального опыта, социальных функций, а также это процесс внутреннего индивидуального развития личности, который направлен на социальное самоопределение через осмысление полученного опыта, дальнейшее его преобразование и возобновление.

Иными словами, социализация личности - это двусторонний процесс усвоения индивидом социального опыта того общества, к которому он принадлежит, с одной стороны, и активного воспроизводства и наращивания систем социальных связей и отношений, в которых он развивается, - с другой.

Как известно, в процессе социализации личность, усваивая социальный опыт общества, в котором находиться, усваивает и нормы поведения этого общества, иначе говоря, усваивает социальные нормы, которые, в свою очередь, подразделяются на мифы, ритуалы, обычаи, религиозные нормы, правовые нормы и моральные нормы.

Правовые нормы тесно взаимосвязаны с другими социальными нормами. Правовые и моральные нормы распространяются на все общество. Они имеют единый объект регулирования - общественные отношения.

От других норм ее отличают, во-первых, всеобщий характер, своего рода обезличенность, распространение на всех участников общественных отношений, независимо от их воли и желания. Во-вторых, правовая норма, в отличие, например, от морали, призвана регулировать внешнее поведение людей, обращена к их воле и сознанию в расчете на определенный поступок. В- 